Jurnal Pujangga Volume 5, Nomor 2, Desember 2019

ISSN P 2443-1478

ISSN E 2443-148

\title{
KRITIK MATERIALISTIK TEKS SASTRA MAJALAH PANDJI POESTAKA (1943--1945)
}

\author{
Kurnia Rachmawati, S.S.,M.A. \\ Universitas Nasional Jakarta \\ 085725302990 \\ Kurniarachmawati90@gmail.com
}

Received September 12, 2019, Revised October 10, 2019, Approved November 27, 2019

\begin{abstract}
ABSTRAK
Penelitian ini bertujuan memaparkan struktur ideologi Teks Sastra dalam Majalah Pandji Poestaka pada masa pendudukan Jepang di Indonesia (1943-1945). Pendekatan teori yang digunakan adalah materialisme yang dipaparkan oleh Eagleton. Kritik sastra materialistik mangasumsikan bahwa teks sastra tidak bertindak pasif, tetapi secara aktif menentukan proses produksi dan struktur ideologi yang membentuknya. Karya sastra merupakan produk interaksi dan artikulasi aspek eksternal dan internal teks. Skema kritik sastra materialistik memosisikan aspek eksternal berada di luar teks yang terdiri atas kontituen-kontituen ideologi yang meliputi: corak produksi umum, ideologi umum, corak produksi sastra, ideologi kepegarangan, dan ideologi estetik. Internal teks merujuk pada ideologi teks yang merupakan produk dari interaksi dan artikulasi kontituen-kontituen eksternal teks yang telah dijabarkan sebelumnya dan membentuk serangkaian tegangan, pengolahan dan transformasi. Hasil Penelitian ini menunjukkan bahwa teks yang berupa Teks Sastra dalam Majalah Pandji Poestaka merupakan hasil artikulasi dominasi kekuasaan Jepang yang menerapkan sistem pemerintahan fasisme-militersme. Mobilization and Control merupakan teknik Jepang guna mendominasi kekuatan dan relasi produksi di Indonesia. Dominasi tersebut mengakibatkan tekanan dan ketimpangan dalam masyarakat, sehingga memunculkan kontestasi ideologi yang diusung oleh para pejuang nasionalis, gerakan bawah tanah, hingga pemberontakan masyarakat kelas bawah yaitu petani. Simpulannya pemberontakan tesebut melahirkan ideologi nasionalisme, sosialisme hingga anarkisme yang memiliki cita-cita yang sama yaitu semangat kebebasan, anti imperialisme, kemerdekaan dan bayangan akan sebuah bangsa (nation).
\end{abstract}

Kata Kunci: Struktur Ideologi, Teks Sastra Pandji Poestaka, Materialisme Eagleton.

\begin{abstract}
This study describes the ideology structure of Teks Sastra in Pandji Poestaka magazine during the Japanese colonial Indonesia (1943-1945). Theory applied in this study is Eagleton's materialism. This critic concerns on how a literary work acts in the process of production and in shaping the ideology structure. In this case, a literary work is regarded as a product of interaction and articulation in external and internal aspects of the text. The materialism critic places the external aspect outside the text, includes ideology constituents, such as general mode of production, general ideology, literary mode of production, author ideology, and aesthetic ideology. Meanwhile, this critic refers the internal aspect to ideology of the text. This ideology is a product of those constituents' interaction and articulation that form a sequence of exertions, accomplishment, and transformation. The result of the study shows that the text Teks Sastra in Panjdi Poestaka magazine is articulation of Japanese domination that applied fascism-militarism in their colonial. In order to dominate the strength and the production relation in Indonesia, Japan also uses mobilization and control technic. Therefore, there is inequality in society and they are pressured. This leads the society to do many kinds of struggle to fight the Japanese domination. The struggles produce the
\end{abstract}

ideology of nationalism, anti-imperialism. Besides, Indonesian wants to reach the Independence and to have a nation.

Key Words: Structure of Ideology, Teks Sastra Pandji Poestaka, Materialism, Eagleton. 


\section{PENDAHULUAN}

\section{Latar Belakang}

Karya sastra pada masa pendudukan Jepang -sebagaimana yang biasa terjadi pada kekuasaan rezim fasis- menjadi salah satu alat propaganda guna mencapai tujuan-tujuan tertentu. Di bawah kontrol ketat pemerintah militer (Gunseikanbū), seluruh kegiatan ekonomi-produksi, sirkulasi, dan distribusi, termasuk karya sastra, secara ketat dikontrol melalui peraturan-peraturan Pemerintah. Tidak ada kebebasan dalam kegiatan politik dan berkarya karena rakyat diharapkan memiliki pemikiran yang seragam.

Zaenal Arifin mengatakan bahwa karya sastra dianggap sebagai media paling efekti dalam mengubah paradigma masyarakat. Hal ini menunjukkan bahwa di dalam karya sastra terdapat nilai yang sarat kepentingan. Perubahan paradigma mendorong masyarakat yang cederung berpola pemikiran traditional ke pola pemikiran modern (2019: 46)

Penerbitan buku, karya sastra, radio, film, surat kabar dan berbagai pertunjukan menjadi alat propaganda untuk mencapai tujuan tersebut. Penerbitan buku, majalah, dan surat kabar mendapat kontrol yang cukup ketat. Keimin Bunka Shidoso --pusat kebudayaan- dan Jawa Shinbukai yang diciptakan Jepang menjadi bukti nyata akan propaganda dan kontrol tersebut, agar para pengarang dan budayawan menciptakan karya yang mendukung politik Jepang.

Jepang mengarahkan agar masyarakat Indonesia -tidak terkecuali Jawa- belajar dan “menjadi” Jepang dari segi kepribadian dan tata cara hidup. Bahasa daerah (Jawa) hanya dikenalkan di kelas satu dan dua, bahasa Indonesia menjadi pengantar dalam pendidikan dan bahasa Jepang wajib diperkenalkan dan digunakan di sekolah. Tidak berhenti pada pembatasan penggunaan bahasa Jawa di dunia pendidikan dan kalangan sekolah, Jepang juga melarang segala penerbitan berbahasa Jawa. Padahal, Panjebar Semangat dan Kajawen adalah dua majalah yang menjadi media penting bagi persebaran sastra Jawa pada masa kolonial. (2001: 212)

Surat kabar yang terbit harus berada di bawah pengawasan badan sensor, Jawa Shinbukai. Badan ini bertugas sebagai pengawas surat kabar yang terbit dan beredar di Jawa. (Poerponegoro dan Notosusanto, 1990: 54)

Jepang mulai merasa bahwa tekanan dan paksaan akan penggunaan bahasa Jepang sebagai bahasa wajib di tataran pendidikan belum manampakkan hasil yang maksimal. Setelah satu tahun berkuasa (1943) Jepang menyadari bahwa justru bahasa daerah (Jawa)-lah yang 
Jurnal Pujangga Volume 5, Nomor 2, Desember 2019

ISSN P 2443-1478

ISSN E 2443-148

mampu menjadi alat propaganda paling efektif. Jepang hanya mengizinkan penerbitan karyakarya sastra Jawa hanya melalui majalah berupa lembaran sisipan, yaitu di majalah Pandji Poestaka penerbitan Balai Pustaka.

Kecenderungan pembacaan teks karya sastra yang hanya sekadar memaknai suatu karya yang telah jadi dan siap konsumsi perlu mendapatkan perhatian. Perlu kiranya memosisikan karya sastra sebagai persoalan yang perlu dipahami melalui relasi dan faktor-faktor yang terkadang justru dikesampingkan, seperti lembaga penerbitan, cara produksi sastra, ideologi pengarang, relasi kekuasaan, dll. Penelitian ini mencoba memperhatikan fenomena tersebut dalam upaya untuk memahami karya sastra Jawa dalam Teks Sastra-Teks Sastra, Majalah Pandji Poestaka.

Eagleton berpendapat bahwa karya sastra seharusnya dipahami sebagai 'praktik material'(1990:54) Perspektif kritik sastra materialistik memungkinkan studi ini mempertanyakan kebenaran penafsiran konvesional atas teks-teks karya sastra Jawa dalam Teks Sastra-Teks Sastra, Pandji Poestaka di atas dengan menyoroti persoalan ideologi yang diartikulasikan dalam proses produksi Teks Sastra tersebut. Penelitian ini lebih memfokuskan pada upaya untuk melihat seberapa jauh diskusi karya tersebut dan dapat menjelaskan masalah yang diangkat dalam penelitian ini. Selanjutnya penelitian ini bertujuan untuk mengkaji persoalan idelogi dalam Teks Sastra Pandji Poestaka.

\section{Rumusan Masalah}

Berdasarkan latar belakang di atas memunculkan beberapa masalah yang akan dibahas dan dikaji dalam penelitian ini, yaitu persoalan ideologi yang hadir dalam karya sastra sebagai

proses interaksi dan artikulasi atas unsur-unsur eksternal yang bertransformasi di dalam struktur internal teks. Di dalam teks, artikulasi kedua unsur tersebut memunculkan serangkaian tegangan yang merupakan ideologi pada teks sastra, Majalah Pandji Poestaka dan akan tampak dalam pembahasan melalui masalah-masalah berikut.

1. Bagaimana corak produksi umum, corak produksi sastra dan ideologi kepengarangan yang merupakan struktur kontituen eksternal teks sastra yang terdapat dalam majalah Pandji Poestaka 1943-1945?

2. Bagaimana pengolahan ideologi umum dan ideologi estetik dalam memproduksi struktur internal teks yang ditandai dengan ideologi tekssastra dalam majalah Pandji Poestaka 1943--1945? 


\section{Tujuan Penulisan}

Sejalan dengan latar belakang dan rumusan masalah, maka tujuan penelitian ini adalah sebagai berikut.

1. Menjelakan struktur konstituen ideologi eksternal teks yang berupa corak produksi umum, corak produksi sastra dan ideologi kepengarangan. Diasumsikan karya sastra Jawa berupa teks sastra, Majalah Pandji Poestaka merupakan produk dari interaksi unsur-unsur tersebut.

2. Menjelaskan struktur ideologi internal teks melalui proses pengolahan ideologi umum dan ideologi estetik. Asumsinya adalah ideologi internal teks merupakan produk pengolahan dari kedua unsur tersebut yang merujuk pada teks sastra, Majalah Pandji Poestaka.

\section{Tinjauan Pustaka}

Materialistik yang digunakan dalam penelitian kritik sastra Marxis merupakan kata sifat dari materialisme, kata yang memiliki arti hampir sama yang digunakan oleh Marx ketika berbicara mengenai faktor penentu sejarah, yaitu bagaimana cara manusia menghasilkan apa yang dibutuhkannya untuk hidup atau produksi kebutuhan material manusia. Seperti yang telah dipaparkan sebelumnya Eagleton mengatakan bahwa karya sastra merupakan sebuah praktik

materialistik, yang mana merupakan produk interaksi struktur-struktur kontituen yang terdiri dari faktor eksternal dan internal, berikut pemaparannya:

\section{Aspek Eksternal Berupa Struktur-Struktur Konstituen Ideologi}

Eagleton memaparkan dalam bukunya Criticism and Ideology bahwa kategori faktor eksternal meliputi corak produksi umum, corak produksi Sastra, ideologi umum, ideologi kepengarangan, dan ideologi estetik. Struktur-struktur konstituen tersebut dijabarkan sebagai berikut:

\section{a. Corak Produksi Umum}

Corak produksi umum adalah kesatuan beberapa kekuatan dan relasi sosial produksi material, yang dimaksud dengan kekuatan produksi adalah bahan, alat, dan teknik produksi. Sementara itu, relasi soial produksi adalah posisi yang menunjukkan hubungan seseorang dengan unsur-unsur kekuatan produksi dan hubungan yang mengatur interaksi pihak yang terlibat dalam 
Jurnal Pujangga Volume 5, Nomor 2, Desember 2019

ISSN P 2443-1478

ISSN E 2443-148

proses produksi. Setiap formasi sosial ditandai oleh gabungan beberapa corak produksi yang salah satunya dominan. Istilah umum sengaja dikenakan untuk merujuk pada mode dominan dan juga untuk membedan dengan struktur yang kedua. (Eagleton, 1998 : 45)

\section{b. Ideologi Umum}

Ideologi Umum menurut Eagleton didefinisikan sebagai berikut:

Relativety coherent set of 'discourse' of values, representations and belideologi estetikfs which, realized in certain material apparatus and related to structres of material producton, so reflect the experideologi estetikntal relations of individual subject to their social condicions as to guarantee those misperceptions of 'real' which contribute to the reproduction of the dominant social relations

[segenap wacana yang relative koheren tentang nilai, representasi, dankeyakinan yang diwjudkan dalam perangkat material dan hubungan konkret dari subjek-subjek individu dengan kondisi sosialnya untuk menjamin salah persepsi atas kenyataan sesungguhnya yang memberikan sumbangan kepada reproduksi relasi sosial dominan] (Eagleton, 1998 : 54).

\section{c. Corak Produksi Sastra}

Corak Produksi Sastra dipahami sebagai a unity of certain forces and social relations of literary in a particular social formation [kesatuan beberapa kekuatan dan relasi sosial produksi sastra dalam formasi sosial tertentu]. Kekuatan produksi sastra adalah bahan, alat, dan teknik produksi sastra. Sementara itu, relasi sosial produksi sastra adalah posisi yang menunjukkan hubungan seseorang dengan unsur-unsur kekuatan produksi sastra dan hubungan yang mengatur interaksi orang pihak yang terlibat dalam proses produksi sastra. Pada setiap formasi sosial terdapat sejumlah corak produksi sastra yang salah satunya dominan.

\section{d. Ideologi Kepengarangan}

Ideologi Kepengarangan merupakan efek cara pandang menyisipkan biografinya ke dalam ideologi umum yang dipengaruhi secara bersamaan oleh sejumlah faktor yang berbeda: kelas sosial, jenis kelamin, kebangsaan, agama, wilayah geografis, dan sebagainya. Proses pembentukannya tidak terpisah oleh ideologi umum. Pembentukan keduannya dapat berpola reproduktif dan kontradiktif. (Eagleton, 1998 : 58 - 59)

\section{e. Ideologi Estetik}

Ideologi estetik adalah wilayah estetik spesifik ideologi umum yang diartikulasikan bersama dengan wilayah-wilayah lainnya seperti etika, agama, dan hubungannya dengan dominasi dan subordinasi yang ditentukan akhirnya oleh corak produksi umum. 
Ideologi estetik adalah "formasi yang secara internal" yang melibatkan sejumlah subsector. Sastra hanyalah salah satunya. Sementara itu, subsector sastra sendiri mencakup "teori sastra, praktik kritik, tradisi sastra, ragam (genre), konvensi, perangkat dan wacana". Ideologi estetik berurusan dengan upaya "penandaan (signifikasi) fungsi, arti, dan nilai estetik dalam suatu formasi sosial yang pada gilirannya merupakan bagian dari "ideologi kebudayaan" dalam ideologi umum. Ideologi estetik merepresentasikan "relasi saling reproduktif" antara ideologi umum dan corak produksi sastra, dan relasi ini memproduksi ideologi produsen, produk, dan konsumen, juga kegiatan-kegiatan produksi, transaksi, dan konsumsi yang terdapat dalam corak produksi sastra (Eagleton, 1998: 60-62).

\section{Struktur Ideologi Teks Sebagai Aspek Internal}

Dalam Criticism and Ideology: A Study in Marxist Literary Theory, Eagleton menjelaskan teks sebagai produksi interaksi struktur-struktur konstituennya. Setiap karya sastra merupakan hasil kerja oleh banyak pihak, disamping kerja pengarangnya (Eagleton, 1998:44). Hal ini menandakan bahwa, menurut Eagleton, setiap teks tidak dapat dijelaskan hanya dari sudut kerangka mano-causality/ kausalitas tunggal, tetapi overdetermination/ kausalitas ganda,

sehingga teks merupakan produk interaksi berbagai elemen dan teks juga memproduksi dan menentukan dirinya sendiri.

Eagleton tidak hanya memosisikan teks berdasarkan faktor eksternal semata, tetapi menguraikan produksi teks sebagai proses yang dilakukan oleh interaksi struktur-struktur konstituennya, tetapi juga dari dalam teks, yaitu dengan memaparkan relasi antara teks dan ideologi dan sejarah.

\section{HASIL DAN PEMBAHASAN}

\section{Kontrol dan Mobilisasi: Corak Produksi Umum}

Guna melihat corak produksi umum di Indonesia pada masa pendudukan Jepang, perlu kiranya memperhatikan komponen-komponen corak produksi umum yang meliputi kekuataan produksi yang mendominasi dan relasi sosial yang sosial produksi material pada masa itu. 
Jurnal Pujangga Volume 5, Nomor 2, Desember 2019

ISSN P 2443-1478

ISSN E 2443-148

Kekuataan produksi dan relasi sosial produksi tersebut tidak dapat dilepaskan dari kondisi ekonomi yang menjadi salah satu faktor kekuataan produksi yang meliputi bahan, alat, dan teknik produksi.

Kekuataan produksi pada masa pendudukan Jepang, berhubungan erat dengan kebijakan yang digunakan untuk menguasai Indonesia guna kemenangan perang, yaitu berupa strategi dalam bentuk kontrol dan mobilisasi. Kontrol Jepang nampak dalam beberapa peristiwa dan lembaga seperti transformasi pertanian, rômusha, rukun tetangga/ tonorigumi dan koperasi desa/ nogyô kumiai. Sedangkan, guna mempermudah dan meningkatkan kekuataan produksi tersebut, sebagaimana yang terjadi pada rejim fasis yaitu muncul propaganda guna memobilisasi massa.

Tuntutan militer Jepang yang tinggi akan kebutuhan perang dan berhentinya perdagangan luar negeri mengakibatkan perubahan yang radikal dalam keseimbangan pasokan dan permintaan (supplay an demand) komoditas. Menghadapi permasalahan ini, pemerintah mencoba memengaruhi penduduk desa (Jawa) untuk menyesuaikan sistem produksi dengan mempertimbangkan kondisi yang berubah semacam ini.

Kontrol dilakukan dengan membatasi produksi tanaman keras, sedangkan bahan pangan dan makanan yang sangat dibutuhkan untuk perang harus ditingkatkan. Tidak cukup hanya sekadar kontrol akan produksi, pemerintah harus mengumpulkan hasil produksi secara efektif dan efisien. Dampaknya, terjadi tranformasi pertanian di pedesaan Jawa, karena sistem yang diterapkan guna peningkatan produksi bahan pangan tersebut berbeda dengan sistem yang digunakan sebelumnya oleh petani Jawa, yaitu melalui penggunaan bibit jenis baru dan inovasi teknik dalam bercocok tanam.

Guna mempermudah tercapainya tujuan-tujuan ekonomi tersebut, Jepang dengan berbagai cara berusaha menarik rakyat pedesaan ke arah kerja yang lebih 'positif' (mobilisasi). Mobilisasi yang paling nampak adalah melalui lembaga propaganda. Jepang membentuk sebuah departemen khusus yang berdiri sendiri di dalam pemerintahan militer (Gunseikanbu).

Di bawah pemerintahan militer (Gunseikanbu) berdiri departemen paling independen yaitu Sendenbu atau dikenal sebagai Departemen Propaganda. (Kurusawa, 2015: 247) . berikut adalah tabel nama dan bidang operasi propaganda di bawah Sendenbu :

\begin{tabular}{|l|l|l|}
\hline \multicolumn{2}{|c|}{ Organisasi Propaganda } \\
\hline Nama Organisasi & Didirikan & Fungsi \\
\hline Jawa Hôsô Kanrikyoku & Oktober 1942 & $\begin{array}{l}\text { Domestic broadcasts (management } \\
\text { entrusted) to NHK. the Japanese } \\
\text { (Biro Pengawas Siaran }\end{array}$ \\
jawa) & & radio broadcast \\
\hline
\end{tabular}


Jurnal Pujangga Volume 5, Nomor 2, Desember 2019

ISSN P 2443-1478

ISSN E 2443-148

\begin{tabular}{|l|l|l|}
\hline $\begin{array}{l}\text { Jawa Shinbukai } \\
\text { (Perusahaan Koran Jawa) }\end{array}$ & Desember 1942 & $\begin{array}{l}\text { Newspaper publishing (entrusted to } \\
\text { the management of the Asahi } \\
\text { Shimbun) }\end{array}$ \\
\hline
\end{tabular}

\begin{tabular}{|c|c|c|}
\hline Dômei (Kantor Berita) & Oktober 1942 & correspondence \\
\hline $\begin{array}{c}\text { Jawa Engeki Kyôkai } \\
\text { (Perserikatan Oesaha } \\
\text { Sandiwara Jepang) }\end{array}$ & Tidak diketahui & production of theatrical art \\
\hline $\begin{array}{c}\text { Nihon Eigasha atau } \\
\text { Nichi'ei (perusahaan film } \\
\text { Jepang) }\end{array}$ & April 1943 & film production \\
\hline $\begin{array}{c}\text { Eiga Haikyûsha atau } \\
\text { Eihai (Pengusahaan } \\
\text { Pendistribusian Film) }\end{array}$ & April 1943 & film production \\
\hline
\end{tabular}

(Sumber: Buku 'Kuasa Jepang di Jawa: Perubahan Sosial di Pedesaan 1942 - 1945, karya Aiko Kurusawa, halaman 248)

Propaganda tersebut memanfaatkan beberapa media audiovisual, seperti film, siaran radio, dan teater, yang dianggap cukup efektif menjangkau rakyat pedesaan yang buta huruf. Karya sastra pun turut menjadi media propaganda, hingga dibentuk sebuah lembaga tambahan di luar Sandebu (biro khusus), yaitu Keimin Bunka Shidoso yang dibentuk pada April 1943 yang juga dipimpin oleh Direktur Sandebu. Tujuan dan kewajiban utama organisasi ini ialah mempromosikan kesenian traditional Indonesia, memperkenalkan dan menyebarkan kebudayaan Jepang, serta mendidik dan melatih seniman Indonesia. Ia dikepalai oleh Direktur Sandebu danterdiri dari lima seksi-seksi administrasi, sastra, musik, seni rupa, dan seni pertunjukan (teater, tari, film) (Kurusawa, 2015:249) . Tiap seksi terdapat orang Indonesia yang merupakan ahli di masing-masing bidangnya. Pada bagian kesusasteraan saat itu dipimpin oleh Armijn Pane di dampingi penasehat atau shidookan Jepang bernama Sakai (Poesponegoro, 1984 : 89).

\section{Ideologi Umum: Kontestasi Fasisme dan Nasionalisme}

Berbicara ideologi-ideologi yang muncul dan berkembang di Indonesia perlu kiranya menengok bagaimana awal mula sebuah ideologi muncul. Feith dan Catles (1998 : xxxix) melihat bahwa perkembangan pemikiran ideologis Indonesia diawali dari keberadaan kaum cendekiawan muda pada tahun 1900an yang memiliki kesempatan untuk belajar ke luar negeri. Wacana dan perdebatan pada masa itu adalah menyoal kerugian atas penjajahan, imperialisme dan kolinialisasi. Sehingga memunculkan organisasi-organisasi yang bersinggungan dengan 
Jurnal Pujangga Volume 5, Nomor 2, Desember 2019

ISSN P 2443-1478

ISSN E 2443-148

kontestasi politik di Indonesia pada saat itu. Perjalanan kontestasi Ideologi Indonesia pada masa kolonialisme Belanda, setidaknya telah menghadirkan beberapa ideologi, diantaranya adalah traditionalisme Jawa, islamisme, nasinalisme, dan komunis. Namun, runtuhnya Belanda dan kehadrian Jepang hingga mampu menduduki Indonesia, melahirkan ideologi dalam bentuk baru yang dominan, yaitu fasisme.

Eagleton menawarkan gagasan tentang ideologi umum, yang didefinisikan sebagai berikut:

Relativety coherent set of 'discourse' of values, representations and belideologi estetikfs which, realized in certain material apparatus and related to structres of material producton, so reflect the experideologi estetikntal relations of individual subject to their social condicions as to guarantee those misperceptions of 'real' which contribute to the reproduction of the dominant social relations

[segenap wacana yang relative koheren tentang nilai, representasi, dankeyakinan yang diwjudkan dalam perangkat material dan hubungan konkret dari subjek-subjek individu dengan kondisi sosialnya untuk menjamin salah persepsi atas kenyataan sesungguhnya yang memberikan sumbangan kepada reproduksi relasi sosial dominan] (Eagleton, 1998: 54).

Ideologi menurut Eagleton mendominasi rangkaian ideologi yang terdapat dalam setiap formasi sosial, dan ideologi umum diproduksi oleh corak produksi umum. Corak produksi umum Indonesia pada masa pendudukan Jepang, seperti yang telah dibahas pada bab sebelumnya, bahwa kekuatan dan relasi produksi dikuasai hampir secara keseluruhan oleh dominasi pemerintahan fasis Jepang.

Salah satu ciri fasisme Jepang tampak pada kebijakan mobilisasi dan kontrol secara otoriter (ekstrem) dengan kekerasan (militer) yang berdampak besar pada masyarakat.

Kemakmuran Indonesia berada di bawah kepentingan Jepang, tanpa kompensasi yang memadai bagi orang Indonesia sendiri. Bahan pangan, minyak, dan kina milik Nusantara dikuras habis, sementara barang-barang kebutuhan pokok yang sangat diperlukan seperti bahan sandang dan onderdil mesin tidak lagi masuk lagi ke Indonesia. Jepang mengawasi kurikulum sekolah secara tangan besi, memaksakan bahasa Jepang menggantikan bahasa

Belanda di sekolah-sekolah menengah atas dan sebagai bahasa resmi di kalangan pemerintah (Mc Kahin, 2013: 147)

Mc Kahin menggambarkan bagaimana rakyat pedesaan pada khususnya, merupakan kelas yang paling menderita karena dominasi Jepang tersebut, yang telah menguasai hampir seluruh produksi, dan menempatkan pedesaan sebagai porosnya. 
Jurnal Pujangga Volume 5, Nomor 2, Desember 2019

ISSN P 2443-1478

ISSN E 2443-148

Perpaduan antara kontrol dan mobilisasi adalah strategi pemerintahan fasisme Jepang yang paling kentara. Mobilisasi digunakan dalam pengertian ganda, yaitu eskploitasi sumber daya dan memaksakan rakyat supaya bekerja sama sepenuhnya dalam upaya perang dengan membangun kesadaran politik bersama.

Setelah pemerintah militer Jepang terbentuk secara resmi, pemerintah militer Jepang di Jawa segera mengendalikan sarana-sarana penerangan untuk publik. Siaran radio, film dan pers ditempatkan di bawah pengawasan pemerintah militer Jepang. Pada bulan Agustus 1942, dibentuk Departemen Propaganda (Sendenbu) dalam lingkup badan Pemerintahan Militer (Gunseikanbu). Departemen Propaganda ini bertanggung jawab atas propaganda dan informasi yang menyangkut pemerintahan sipil, dan merupakan departemen yang terpisah dari Seksi Propaganda Pemerintahan Militer, yang bertanggung jawab atas informasi mengenai operasi militer. Kegiatan Sendenbu ditujukan kepada penduduk sipil di Jawa, meliputi orang Indonesia, Indo-Eropa, minoritas Asia, dan Jepang, sedangkan Seksi Penerangan Angkatan Darat ke-16 melaksanakan propaganda bagi tentara Jepang, tawanan perang, dan warga negara musuh melalui siaran luar negeri. (Dewi Yulianti Sistem Propaganda Jepang di Jawa 1942 -- 1945)

Sebagaimana yang biasa dilakukan oleh negara fasis, propaganda menjadi alat paling efektif untuk memobilisasi massa. Dominasi ideologi fasis yang menindas ini memunculkan pergerakan dari beberapa pemuda Indonesia.

\section{Corak Produksi Sastra di Bawah Lembaga Propaganda}

Kekuataan produksi sastra meliputi bahan, alat dan teknik produksi. Pada masa pendudukan Jepang, sastra Jawa, sebagai contohnya Teks Sastra Pandji Poestaka, berada di

bawah kendali dua lembaga propaganda sekaligus, yaitu Keimin Bunka Shidoso (pusat kebudayaan) dan Jawa Shinbukai.

Sebagai lembaga propaganda, Keimin Bunka Shidoso mencetak pengarang yang sesuai dengan kendali dan keinginan Jepang. Armijn Pane yang merupakan produk lembaga tersebut sekaligus menjabat sebagai pemimpin redaksi majalah Pandji Poestaka memberikan pengaruh dan menjadi pertimbangan atas karya mana yang pantas dan tidak pantas sesuai kehendak pemerintahan Jepang, tidak terkecuali untuk Teks Sastra di Pandji Poestaka.

Di bawah pemerintahan militer (Gunseikanbu) berdiri departemen paling independen yaitu Sendenbu atau dikenal sebagai Departemen Propaganda (Kurusawa, 2015: 247). Jawa 
Jurnal Pujangga Volume 5, Nomor 2, Desember 2019

ISSN P 2443-1478

ISSN E 2443-148

Shinbukai (perusahaan Koran Jawa) di bawah Sandebu merupakan organisasi yang berfungsi mengelola surat kabar di bawah management koran Asahi Shinbun. Surjomihardjo mengungkapkan bahwa, setelah berakhirnya pemerintah Hindia Belanda, sejak pendudukan militer Jepang semua media pers ada di bawah pengawasan pemerintah militer dan dipergunakan sebagai alat propaganda (2004: 98).

Kebijakan Jawa Shinbukai dalam mengawasi media massa, 'mematikan' dan memutus rantai perkembangan sastra Jawa, yang pada perkembanganya sebelumnya, sastra Jawa banyak terlahir melalui media massa.

Jepang melarang semua penerbitan berbahasa Jawa. Padahal, sebelumnya majalah Panjebar Semangat dan Kajawen merupakan media penting bagi penerbitan Sastra Jawa. Jepang tidak memberikan izin yang istimewa pula bagi penerbitan surat kabr dan media lainnya. Semua surat kabar diawasi oleh badan sensor. Surat kabar yang terbit harus berada di bawah pengawasan Jawa Shinbukai, yaitu badan yang bertugas sebagai pengawas surat kabar yang terbit dan beredar di Jawa. Poesponegoro dalam (Widati, 2001: 212)

Masa pendudukan Jepang dianggap sempat memutus rantai perkembangan sastra Jawa dikarenakan Kadjawen dan Panjebar Semangat yang telah banyak memberikan banyak kontribusi bagi khazanah sastra Jawa harus dihentikan. Dimana Kadjawen merupakan majalah berbahasa Jawa produk Balai Pustaka yang kali pertama diterbitkan tahun 1926. Sedangkan, Majalah Panjebar Semangat adalah produk swasta, non Balai Pustaka yang mulai diproduksi tahun 1933.

\section{Ideologi Kepengarangan: Kedekatan Pada Struktur Dominan}

Objek material berupa sebelas Teks Sastra Pandji Poestaka menghadirkan tiga nama pengarang yang berbeda, diantaranya adalah Poerwadhie Atmodihardjo, Soebagijo I. Notodihardjo, dan Poerwadarminta/ Ajirabas. Analisis ini akan menunjukkan ideologi masingmasing dari kelima pengarang dalam melahirkan karya sastra Jawa pada masa pendudukan Jepang.

Terry Eagleton (1998: 58 - 58) menjelaskan bahwa ideologi kepengarangan, merupakan efek cara pengarang menyisipkan biografinya kedalam ideologi umum (1998 : 58 -- 58). Artinya proses pembentukan ideologi pengarang-pengarang tersebut tidak terpisahkan dari ideologi umum yang muncul di Indonesia pada masa okupasi Jepang. Pembentukan keduanya bisa berpola reproduktif atau kontradiktif. Namun ini bukan berarti ideologi kepengarangan identik 
Jurnal Pujangga Volume 5, Nomor 2, Desember 2019

ISSN P 2443-1478

ISSN E 2443-148

dengan idologi umum. Sedangkan, terhadap ideologi teks, teks merupakan produk pengolahan secara estetik atas ideologi umum. Namun hal ini tidak berarti bahwa teks sastra hanya dipusatkan pada subjek individu yang memproduksinya atau sebaliknya, subjek individu dilenyapkan ke dalam bentuk-bentuk estetik ideologi umum. Hubungan antar ideologi ini akan tergambar melalui biografi singkat pengarang dan bagaimana ideologi umum akan menghidupi, mengalami dan merepresentasikan pengarang-pengarang tersebut

Poerwadhie dan Soebagijo menjadi pengarang yang ditunjuk Jepang guna mengelola lembaran berbahasa jawa dalam Panji Poestaka ini (2001 : 216). Lembaran berbahasa Jawa yang dimaksud adalah rubrik "Djawa" yang meliputi artikel-artikel berupa essay, Teks Sastra, dan geguritan. Peran Poerwadhie tidak hanya sekadar menjadi pengarang, namun juga redaktur yang mengelola dan menentukan layak dan atau tidaknya karya sastra tersebut diterbitkan.

Sebagai penanggung jawab rubrik 'Djawa' yang berada di bawah kontrol dan sensor lembaga propaganda Jawa Shinbukai, menunjukkan keberpihakan Poerwadhie kepada Jepang, ideologi kepengarangan Poerwadhie pun tidak mampu dilepaskan dari kepentingan penguasa Jepang saat itu. Dominasi ideologi fasisme-militerisme turut hadir dalam karya-karya Poerwadhie. Sangat jelas bagaimana Poerwadhie turut mempropagandakan dan seruan guna kemenangan perang. Propaganda tersebut meliputi romantisme hidup di Jawa dan bertani, turut menyerahkan hasil padi serta sebagian penghasilan kepada pemerintah serta menonjolkan keikutsertaan rakyat menjadi prajurit pembela tanah air. Keseluruhan seruan tersebut merupakan bentuk Jepang memobilisasi dan mengontrol rakyat Indonesia guna ikut serta berperan membantu Jepang memenangkan perang Asia Timur Raya.

Nama pengarang ketiga adalah Poerwadarminta, dia pernah mengajar bahasa Jawa dan Melayu di Tokyo, Jepang. Hal ini menunjukkan jika tanpa ada kedekatan antara Poer dan Jepang, dia tidak akan mendapatkan kesempatan semacam ini.

Berkat keahliannya di bidang bahasa, Poerwadarminta diminta menjadi dosen bahasa Indonesia di sekolah bahasa Asing (Gucho Hugo Gakko) di Tokyo, Jepang, tahun 1923 1937. Sambil mengajar di sana, ia belajar bahasa Jepang beserta aksara Katakana, Hiragana, Kanji, sekaligus memperdalam bahasa Inggris. Pada tahun 1935 ia berhasil menerbitkan buku pelajaran bahasa Jepang, Punca Bahasa Jepang. (2006 : 47)

Kedekatan yang telah terjalin lama dengan Jepang, bahkan sebelum Jepang menguasai Indonesia, menunjukkan ideologi Pengarang yang berpihak kepada Jepang. Karya-karya yang 
Jurnal Pujangga Volume 5, Nomor 2, Desember 2019

ISSN P 2443-1478

ISSN E 2443-148

dia ciptakan tidak sedikit yang menyoal Jepang dan seolah ingin membantu Jepang dalam mempropagandakan bahasa-bahasa Jepang di Indonesia pada masanya.

\section{Ideologi Estetik}

Ukuran kesusatraan Jawa pada masa pendudukan Jepang tentunya berbeda dengan kondisi Indonesia pada masa damai. Karya-karya yang beredar harus mengandung cita-cita yang menimbulkan cinta terhadap tanah air, mengobarkan semangat kepahlawanan dan menganjurkan semangat bekerja (Syamsuddin, 1994 : 61). Karya-karya yang berisi ratapan dan tangisan serta percintaan yang semata-mata mengumbar kerinduan diharapkan untuk disimpan untuk dirinya sendiri. Dianjurkan kepada pujangga untuk sadar akan artinya bagi masyarakat. Hasil ciptaannya harus dapat membimbing masyarakat dan memberikan masyarakat tempat berpegang. Karyakarya yang menimbulkan keragu-raguan dan kebimbangan harus dijauhkan (Jassin, 2013 : 8).

Kehidupan yang serba susah dalam ekonomi, politik maupun kebudayaan, mengajarkan kepada para pengarang Indonesia supaya belajar hemat dengan kata-kata. Setiap kalimat, setiap alinea ditimbang dengan matang. Juga segala superlativisme dan perbandingan yang penuh retorika yang menjadi ciri dan kegemaran para pengarang Pujangga Baru telah ditinggalkan. Dalam pemilihan materi pun dibuat dengan lebih sederhana. Hal yang menjadi

perhatian para pengarang bukanlah lagi masalah yang pelik-pelik ataupun kehidupan yang rumit-rumit melainkan kenyataan sehari-hari yang tampak dengan mata kepala (Rosidi, 2013: 89 -- 90)

\section{Teks Sebagai Propaganda: Rekonstruksi Ideologi Fasisme}

Teks berupa Teks Sastra Pandji Poestaka di atas menggambarkan ketertundukan rakyat kepada dominasi kuasa Jepang. Dimana teks sebagai propaganda tidak merepresentasikan derita rakyat Indonesia. ideologi fasisme Jepang terkontruksi dalam istilah-istilah baru yang diolah sedemikian rupa oleh pengarang melalui proses estetik, yang mana teks telah melalui banyak saluran kontrol dan sensor ketat dari dua lembaga propaganda sekaligus; Jawa Shinbukai dan Keimin Bunka Shidoso. Sekilas memang ideologi teks yang muncul adalah sebagai bentuk dukungan terhadap struktur dominan yang dibentuk Jepang dan sekaligus mempropagandakan kebijakan mereka. Analisis terhadap teks Teks Sastra ini menunjukkan bahwa teks membongkar aspek ekternal atau struktur ideologi yang terdiri dari cara produksi umum, ideologi umum, cara produksi sastra, ideologi kepengarangan, dan ideologi estetik. Hal ini tampak dalam kutipan sebagai berikut:

Saja malih samangké wonten andjoeran:, hasil boemi berlipat ganda, tambah tegoeh Asia Raja" Anggenipoen lampah tani Dèn Poerwa saja katingal mempeng pindo, awit 
mèndel-mèdel Dèn Poerwa poenika inggih tijang ingkang bersemangat lan insap. (Tanggap lan Tandang ing Garis Wingking)

Terjemahan:

Apalagi ada anjuran: 'hasil bumi berlipat ganda, semakin teguh Asia Raja', Den Poerwa bekerja semakin lebih giat, apalalagi memang Den Poerwa ini merupakan orang bersemangat.

djaman saiki kok mikir marang bebatèn, ikoe ora prajoga. Kang mengkono maoe kena diarani 'kepentingan diri sendiri' djaman saiki kapribadèn koedoe ilang, diganti gotongrojong. Moela saka panemoeko, lan bab iki wis dakpikir mateng tenan, lan... ngélingi kapreloean masarakat Djawa Baroe" (Tanggap lan Tandang ing Garis Wingking)

artinya:

Jaman sekarang kok memikirkan keuntungan, itu tidak baik. Yang seperti itu disebut 'kepentingan diri sendiri', jaman sekarang kepentingan diri sendiri harus hilang, diganti

gotong-royong, maka menurutku, dan ini sudah aku piker baik dan sungguh sungguh, mengingat keperluan masyarakat Djawa Baroe

\section{PENUTUP}

\section{Simpulan}

Struktur ideologi dalam Teks Sastra Pandji Poestaka merupakan praktik material yang meliputi aspek eksternal dan internal teks. Aspek eksternal teks Teks Sastra Pandji Poestaka merupakan hasil artikulasi dominasi kuasa Jepang di Indonesia yang menerapakan kebijakan mobilisasi dan kontrol yang ketat. Kondisi tersebut menyebabkan corak kehidupan masyarakat Indonesia mengalama perubahan. Pendudukan dan penjajahan berakibat pada perubahan struktur sosial, politik, ekonomi, dll. Kekuatan dan relasi produksi pada sektor-sektor penting didominasi oleh pemerintahan Jepang. Kondisi semacam ini menyebabkan ketimpangan, sehingga muncul beberapa pemberontakan melalui pejuang nasionalis, pemuda gerakan bawah tanah, petani dan kyai sehingga memunculkan ideologi-ideologi baru di Indonesia.

Ideologi-ideologi yang muncul seperti nasionalisme, sosialisme dan anarkisme merupakan manifesti dari derita rakyat. Namun, ideologi yang dominan menguasai rakyat adalah fasisme-militerisme yang merupakan ideologi yang diusung oleh Jepang sejak awal menguasai Indonesia. Dominasi kuasa Jepang dengan ideologi fasisme yang jelas otoriter dan tidak mengenal demokrasi serta militerisme yang menerapkan aturan dengan kekerasan, hal ini mencengkram rakyat indonesia. Pejuang nasionalis dan gerakan bawah tanah memiliki cita-cita 
ISSN P 2443-1478

ISSN E 2443-148

yang sama akan sebuah kemerdekaan, kebebasan, dan bayangan akan sebuah bangsa (nation) yang mandiri. Nasionalime muncul dengan bayangan yang sama tentang komunitas mereka. Suatu bangsa yang berbentuk dan merdeka.

Sastra tidak luput dari pengaruh kebijakan mobilisasi dan kontrol, Sastra menjadi alat mobilisasi dan propaganda guna kemenangan perang. Keimin Bunka shidoso atau lembaga propaganda berbasis kebudayaan diciptakan guna mengontrol kerja pengarang. Majalah pun dikendalikan Jawa Shinbukai,tidak terkecuali majalah berbahasa Jawa. Atas kontrol ini sastra Jawa dalam bentuk Teks Sastra selama pendudukan Jepang hanya mendapatkan tempat dalam

bentuk sisipan di Majalah Pandji Poestaka. Hal ini tentu memengaruhi ideologi estetik dan ideologi kepengarangan. Secara estetik produksi teks sastra yang muncul hanya sebatas teksteks pendek berupa cerpen/ Teks Sastra dan puisi, jarang ditemukan teks panjang dalam bentuk roman dan novel. Terjadi dualisme kepentingan dalam subjek pengarang, antara harus tunduk pada struktur dominan dan atau menumbuhkan semangat nasionalime.

Dilihat dari aspek internal teks, analisis terhadap Teks Sastra-Teks Sastra tersebut menunjukan bahwa teks membongkar struktur konstituen ideologi (eksternal) dan kemudian merekonstruksi kembali kedalam istilah-istilahnya sendiri melalui proses estetik. Lantas teks bertransformasi membentuk struktur ideologi yang menghasilkan propaganda-propaganda guna memobilisasi rakyat indonesia demi kemenangan perang. Namun, struktur ideologi yang berupa propaganda tersebut juga mengekspresikan semangat anti-imperialisme dan kolinialisme yang terselip dalam teks-teks tersebut. 


\section{DAFTAR PUSTAKA}

Eagleton, Terry. 1976. Marxis and Literary Criticism. New York : Methund \& co. Ltd

Verso . 1998. Criticism and ideology : a Study in Marxis LiteraryTheory. New York: . 2001. The Ideology of Aethetic. Reprinted Oxford : Blackwell Publisher

Ebenstein, William. 2006. Isme-Isme yang Mengguncang Dunia. Yogyakarta : Narasi

Faruk, HT. 2012. Novel Indonesia, Kolonialisme dan Ideologi Emansipatoris. Yogyakarta : Ombak

Frow, John. 1986. Marxism and Literary History. Cambridge, Massachusetts: Harvard University Press

Geertz, Clifford. 2014. Agama Jawa; Abangan, Santri, Priyayi dalam Kebudayaan Jawa. Jakarta : Komunitas Bambu

Kurasawa, Aiko. 1987. Propaganda Media on Java under the Japanese 1942--1945. Jurnal Indonesia no. 44 tahun 1987

2015. Kuasa Jepang di Jawa; Perubahan Sosial di Pedesaan (1942--1945). Depok: Komunitas Bambu

Mangunhardjana,A. 1996. Isme-Isme dalam Etika dari A-Z. Yogyakarta: Kanisius.

McTurnan Kahin, George. 2013. Nasionalisme dan Revolusi Indonesia. Depok: Komunitas Bambu

Poesponegoro, Marwati Djoened dan Nugroho Notosusanto. 2008. Sejarah Nasional Indonesia: Zaman Jepang dan Zaman Republik Indonesia VI. Jakarta: Balai Pustaka

Rosidi, Ajip. 2013. Ikhtisar Sejarah Sastera Indonesia. Jakarta: Pustaka Jaya

Syamsuddin, Agus. 1994. Pusat Kebudayaan (Keimin Bunka Shidoso) di Jawa Pada Masa Pendudukan Jepang 1942--1945. Skripsi. Fakultas Sastra, Universitas Indonesia

Tirto, Suwondo. 2006. Antologi Biografi Pengarang Sastra Jawa Modern. Yogyakarta: Adiwacana

Widati, Sri. dkk. 2001. Ikhtisar Perkembangan Sastra Jawa Modern: Periode Prakemerdekaan. Gadjah Mada University Press: Yogyakarta.

Zaenal, Arifin. 2019. Nilai Pendidikan dan Moral dalam Novel Dendam si Yatim Piatu karya Sintha Rosse. Dalam Pujangga. Volume 5, nomor 1, Halaman 46 --73. Jakarta 